\title{
BOOKS AND SPECIAL VOLUMES IN THE FIELD OF GENETICS, 1950-195I*
}

\author{
DEREK SLOPE \\ John Innes Horticultural Institution, Bayfordbury, Hertford, Herts.
}

Received 27.7 .51

AUERBACH, c. I95I (1942). Notes for Introductory Courses in Genetics. $3^{\text {rd }}$ ed.

Pp. 42. Edinburgh : Oliver \& Boyd.

BABCOCK, E. B. 1950. The Development of Fundamental Ideas in the Science of Genetics.

Pp. 5o. Washington : American Genetic Association.

Bacon, J. S. D. 1951. The Science of Heredity. Pp. viii +192. London: Watts \& Co., The Thinkers' Library.

Bisset, K. A. 1950. The Cytology and Life History of Bacteria. Pp. 136. Edinburgh : E. \& S. Livingstone.

Bourne, G. н. (ed.). I95I (1942). Cytology and Cell Physiology. 2nd ed. Pp. xvi +524 . Oxford : Clarendon Press.

tвoyd, w. c. 1950. Genetics and the Races of Man. Pp. 453. Boston: Little, Brown \& Co., Oxford : Blackwells Ltd.

cameron, g. 1950. Tissue Culture Technique. 2nd ed. rev. Pp. xiitrigr. New York : Academic Press Inc.

CARTER, G. s. 195I. Animal Evolution: A study of recent views of its causes. Pp. $\mathbf{x v}+368$. London: Sedgewick \& Jackson Ltd.

CAspersson, т. o. 1950. Cell Growth and Cell Function. Pp. 185. New York: Norton \& Co., London : Chapman \& Hall.

CAtcheside, D. G. 1951. The Genetics of Micro-organisms. Pp. vii +223. London: Pitman \& Sons.

COLD SPRING HARBOUR. Symposia on Qualitative Biology. 1951. Vol. 15. Origin and Evolution of Man. Pp. xii +425. New York : Long Island Biological Association.

tDarlington, C. D., ANd Mather, K. 1950. Genes Plants and People. Essays on Genetics. Pp. xxi+187. London: Allen \& Unwin.

Demerec, м. (ed.). 1950. Advances in Genetics. Vol. 3. Pp. viii +267 . New York : Academic Press.

demerec, м. (ed.). 1950. Biology of Drosophila. Pp. $\mathrm{x}+632$. New York : Wiley \& Son, London : Chapman \& Hall.

FORD, E. B. 1950. The Study of Heredity. 2nd ed. rev. London: Thornton Butterworth.

†FYFe, J. 1950. Lysenko is Right. Pp. vi +65 . London: Wishart \& Lawrence. thagedoorn, A. L. 1950. Plant Breeding. Pp. 237. London: Crosby Lockwood \& Son.

FISHER, R. A. 1950. Contributions to Mathematical Statistics. New York: John Wiley \& Sons ; London: Chapman \& Hall.

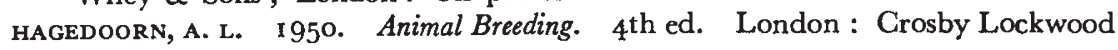
\& Son.

HURST, R. 1951. What's All This About Genetics? Pp. 124. London: Watts \& Co., Thrift Books No. 3 .

thuxley, Julian. 1950. Soviet Genetics and World Science. Pp. $\mathrm{x}+245$. London: Chat to \& Windus.

* Continuation of the list in Heredity, 4, 249, 1950.

+ Reviewed or to be reviewed in Heredity. 
KUCKUCK, H., AND MUDRA, A. I950. Lehrbuch der allgemeinen Pflanzenzüchtung. Pp. $x i+280$. Zurich : S. Hirzel Verlag.

tLerner, x. м. I950. Population Genetics and Animal Improvement, as illustrated by the inheritance of egg production. Pp. xviii +342 . Cambridge : University Press.

makino, s. 1951. Chromosome Numbers in Animals. Pp. 29o. Iowa State College Press, Ames, Iowa.

manton, I. I950. Problems of Cytology and Evolution in the Pteridophyta. Pp. xi+3r6. Cambridge : University Press.

tRACE, R. R., AND SANGer, R. 1950. Blood Groups in Man. Pp. xv+29o. Oxford : Blackwell's Scientific Publications.

RICE, V. A., AND ANDREWS, F. N. 195I. Breeding and Improvement of Farm Animals. $4^{\text {th }}$ ed. Pp. 787. London : McGraw Hill.

scheinfeld, A. r950. The New You and Heredity. 2nd ed. Pp. 6r5. Philadelphia : Lippincott.

SEARS, P. B. 1950. Charles Darwin: The naturalist as a cultural force. Pp. I24. London and New York: Charles Scribner.

Simpson, G. G. 1950. The Meaning of Evolution. A study of the history of life and its significance for man. Pp. $\mathrm{xv}+364$. London : Oxford University Press.

sinnott, E. W., DUNN, L. C., AND Dobzhansky, T. 1950. Principles of Genetics. $4^{\text {th }}$ ed. Pp. 505. New York and London: McGraw Hill.

tsorsby, A. (ed.). 1951. Genetics in Ophthalmology. Pp. $\mathrm{xi}+25 \mathrm{I}+\mathrm{i} 4$. London: Butterworth \& Co.

STEbbins, G. L., JUn. 1950. Variation and Evolution in Plants. Pp. xix +643 . London: Oxford University Press.

TISChler, G. 1950. Die Chromosomenzahlen der Gefässpflanzen Mitteleuropas. Pp. 263. 'S-Gravenhage : Junk.

williams, R. T. (ed.). I950. Biochemical Society Symposium No. 4. Biochemical Aspects of Genetics. Pp. 6o. Cambridge : University Press.

twINGE, O. 1950. Inheritance in Dogs, with special reference to the Hunting Breeds. Pp. ix + 153. New York : Comstock Publ. Co., London : Constable \& Co.

Wishart, J. 1950. Field Trials II : The analysis of covariance. Pp. 34. Cambricige: Commonwealth Bureau of Plant Breeding and Genetics.

$\dagger$ Reviewed or to be reviewed in Heredity. 